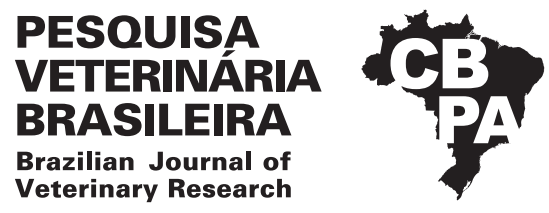

Pesq. Vet. Bras. 39(5):299-303, May 2019 DOI: $10.1590 / 1678-5150-P V B-6038$

Original Article

ISSN 0100-736X (Print)

Livestock Diseases

ISSN 1678-5150 (Online)

\title{
Nervous form of listeriosis in buffaloes ${ }^{1}$
}

\author{
Robert Gustavo S. Prado², Tarcísio Anderson O. Domiciano², \\ Laura Jamille A. Paredes ${ }^{3}$, Pedro S. Bezerra Junior ${ }^{2}$, Washington Luiz A. Pereira ${ }^{3}$, \\ Valíria D. Cerqueira ${ }^{2}$, David Driemeier ${ }^{4}$ and Gabriela Riet-Correa ${ }^{2 *}$
}

\begin{abstract}
Prado R.G.S., Domiciano T.A.O., Paredes L.J.A, Bezerra Jr P.S., Pereira W.L.A., Cerqueira V.D., Driemeier D. \& Riet-Correa G. 2019. Nervous form of listeriosis in buffaloes. Pesquisa Veterinária Brasileira 39(5):299-303. Programa de Pós-Graduação em Saúde Animal na Amazônia, Universidade Federal do Pará, BR-316 s/n, Castanhal, PA 68740-000, Brazil. E-mail: griet@ufpa.br

Listeriosis is a disease that affects several animal species, including humans, and has three different forms of presentation: encephalic, reproductive, or septicemic. The nervous form is caused mainly by the bacterium Listeria monocytogenes. In Brazil, this disease has already been described in sheep, goats, and cattle. There are no reports of the disease in buffaloes in Brazil and worldwide. The objective of this study was to describe an outbreak of listeric meningoencephalitis in buffaloes in the state of Pará, Brazil. The outbreak occurred in a property located in the municipality of Bujaru, in the eastern Amazon, from May to July 2016. In a herd of 47 buffaloes, three animals (Cases 1, 2 and 3), aged $<40$ days, presented a neurological condition with locomotion difficulty characterized by paralysis of the four limbs, hypoesthesia, lateral recumbency, and death. Morbidity was $6.38 \%$ and lethality was $100 \%$. At necropsy, no significant macroscopic lesions were found. Samples of the central nervous system were collected, fixed in $10 \%$ buffered formalin, and routinely processed for histopathological analysis. The main microscopic changes observed were unilateral microabscesses in the brainstem composed predominantly of mononuclear cells, with fewer polymorphonuclear cells, and perivascular cuffs composed mostly of mononuclear cells and few neutrophils. Samples of Cases 1 and 2 revealed Gram-positive bacteria in the areas of necrosis by the Gram's stain technique. Samples of Case 1 were positive in immunohistochemistry for L. monocytogenes. Diagnosis of the nervous form of listeriosis was based on epidemiological data, clinical profile, and immunostaining for Listeria monocytogenes. Results showed that listeriosis should be considered in the differential diagnosis in buffaloes with nervous signs.
\end{abstract}

INDEX TERMS: Nervous form of listeriosis, listeriosis, buffaloes, Listeria monocytogenes, Bubalus bubalis, Pará state, Amazon region, bacterioses.

RESUMO.- [Listeriose nervosa em búfalos.] A listeriose é uma doença que afeta várias espécies animais, incluindo o homem, e possui três formas diferentes de apresentação:

\footnotetext{
${ }^{1}$ Received on November 8, 2018.

Accepted for publication on December 21, 2018.

${ }^{2}$ Postgraduate Program in Animal Health in Amazon, Universidade Federal do Pará (UFPA), BR-316 s/n, Castanhal, PA 68740-000, Brazil. *Corresponding author: griet@ufpa.br

${ }^{3}$ Universidade da Amazônia (Unama), Faculdade de Medicina Veterinária, Centro de Ciências Biológicas e Saúde, Av. Alcindo Cacela 278, Umarizal, Belém, PA 66065-205, Brazil.

${ }^{4}$ Setor de Patologia Veterinária, Departamento de Patologia Clínica Veterinária, Faculdade de Veterinária, Universidade Federal do Rio Grande do Sul (UFRGS). Av. Bento Gonçalves 9090, Prédio 42505, Porto Alegre, RS 91540-000, Brazil.
}

nervosa, abortiva ou septicêmica. A forma nervosa é causada principalmente pela bactéria Listeria monocytogenes. No Brasil a doença já foi descrita em bovinos, ovinos e caprinos, mas não foram encontrados relatos desta doença em búfalos no Brasil e no mundo. 0 objetivo deste trabalho foi descrever um surto de listeriose nervosa em búfalos no estado do Pará, Brasil. O surto ocorreu de maio a julho de 2016, em uma propriedade localizada no município de Bujaru, na Amazônia Oriental. Três bubalinos de um total de 47 animais (Casos 1, 2 e 3), menores de 40 dias, apresentaram um quadro clínico neurológico caracterizado por dificuldade de locomoção, paralisia dos quatro membros, diminuição da sensibilidade cutânea, decúbito lateral e morte. A morbidade foi de $6,38 \%$ e a letalidade de $100 \%$. Na necropsia não foram encontradas lesões macroscópicas significativas. Amostras 
do sistema nervoso central foram coletadas e fixadas em formalina tamponada a $10 \%$ e processadas rotineiramente para análise histopatológica. As principais alterações microscópicas observadas foram microabscessos unilaterais no tronco encefálico, compostos predominantemente por células mononucleares, com menor número de polimorfonucleares, e manguitos perivasculares compostos predominantemente por células mononucleares e poucos neutrófilos. Amostras dos Casos 1 e 2 revelaram bactérias Gram positivas nas áreas de necrose na técnica de Gram. Amostras do Caso 1 resultaram positivas na imuno-histoquímica para L. monocytogenes. 0 diagnóstico da forma nervosa da listeriose foi baseado nos dados epidemiológicos, no quadro clínico patológico e na imunomarcação para Listeria monocytogenes. Os resultados demostram que a listeriose deve ser considerada no diagnóstico diferencial em bubalinos com sinais nervosos.

TERMOS DE INDEXAÇÂO: Listeriose nervosa, búfalos, Listeria monocytogenes, Bubalus bubalis, Pará, região amazônica, bacterioses.

\section{INTRODUCTION}

Listeriosis is an infectious disease caused by the Gram-positive bacterium Listeria monocytogenes with worldwide distribution (George 2002). It affects several animal species, including humans. Three forms of this disease have been identified in domestic animals: septicemic, affecting ruminants, swine, rabbits, and young birds (Low \& Renton 1985, Jones et al. 2000); reproductive, with abortion in sheep and bovines; encephalitic, which presents with meningoencephalitis in sheep, goats, and cattle (Low \& Renton 1985, Schneider 1994, Summers et al. 1995, George 2002). Generally, only one of these three clinical forms is observed in listeriosis outbreaks. Only L. monocytogenes is associated with encephalitis outbreaks (Jones et al. 2000). L. monocytogenes presents worldwide distribution, occurring mainly in areas with temperate climate. L. monocytogenes inhabits the soil or decomposed vegetable matter, and can be isolated from the feces of several domestic and wild animals (George 2002). In Brazil, L. monocytogenes was isolated from the feces and liver of healthy and ill cattle (Hofer et al. 2005), demonstrating the epidemiological role of these potential sources of infection in cases of meningoencephalitis caused by L. monocytogenes in ruminants. In China, Listeria spp., including L. monocytogenes and L. ivanovii, were isolated from the feces of wild rodents, indicating a possible involvement of these animals in the epidemiology of human listeriosis in natural environments (Wang et al. 2017).

In ruminants, the encephalitic disease usually shows low rates of morbidity and high lethality (Vandegraaff et al. 1981, Rissi et al. 2006, 2010). In these cases, infection is often associated with silage feeding or contact with the feces or milk from carrier animals (Vandegraaff et al. 1981, Wilesmith \& Gitter 1986, Rissi et al. 2006). In Brazil, most cases of meningoencephalitis caused by L. monocytogenes in ruminants occur in the hottest months of the year, and most often not in association with silage (Rissi et al. 2006, Sanches et al. 2000).

In Brazil, the encephalitic form of listeriosis in ruminants has already been described in cattle (Sanches et al. 2000, Konradt et al. 2017), goats (Rissi et al. 2006, Guedes et al. 2007, Konradt et al. 2017), and sheep (Mendes et al. 2005,
Ribeiro et al. 2006, Guedes et al. 2007, Rissi et al. 2010, Konradt et al. 2017), but this form of the disease has not been reported in buffaloes to date. Therefore, this study aimed to describe an outbreak of listeric meningoencephalitis in buffaloes.

\section{MATERIALS AND METHODS}

Clinical, epidemiological and necropsy data were provided by the veterinarian responsible for the buffalo herd in the property where the outbreak occurred.

Three Murrah buffaloes (Buffaloes 1, 2, and 3) aged $<40$ days were investigated in a farm located in the municipality of Bujaru in the microregion of Castanhal, Pará state, Brazil. The animals died spontaneously, were necropsied, and had samples collected from the central nervous system (CNS) and organs of the abdominal and thoracic cavities, which were fixed in $10 \%$ buffered formalin and sent to the animal pathology laboratories of the "Universidade Federal do Pará" (UFPA) (Buffaloes 1 and 2) and the "Universidade Federal Rural da Amazônia" (UFRA) (Buffalo 3).

The formalin fixed samples were sectioned and routinely processed for histopathological examination, sliced ( $5 \mu$ thick), and stained using the hematoxylin and eosin (HE) technique. In the CNS samples, sections of the spinal cord, brainstem (rostral and caudal colliculus, pons, and medulla oblongata), cerebral cortex, and cerebellum were analyzed. The Gram's stain technique was used in tissue sections of the pons in Cases 1 and 2 .

Tissue sections of the pons of the three cases were embedded in paraffin and sent to the Department of Veterinary Pathology of the "Universidade Federal do Rio Grande do Sul" (UFRGS) for immunohistochemistry (IHC) for L. monocytogenes. IHC staining was performed according to the protocol described by Konradt et al. (2017), using a primary monoclonal antibody to L. monocytogenes $\left(\mathrm{BD}^{\circledR}, \mathrm{New}\right.$ Jersey) in a 1:200 dilution, in phosphate-buffered saline (PBS). Antigen retrieval was obtained with citrate buffer ( $\mathrm{pH} 6.0$ ) for $10 \mathrm{~min}$ in microwave at maximum power, and background reactions were blocked using a $5 \%$ skim milk solution. The samples were incubated with primary antibodies overnight $(18 \mathrm{~h})$ at $4^{\circ} \mathrm{C}$. The streptavidin-biotin method (LSAB-DAKO) and the substrate chromogen (DAB), followed by hematoxylin counterstaining, were used to develop the reaction. As positive control, positive samples were used in the IHC for L. monocytogenes. Tissue sections incubated in PBS were used as negative control instead of primary antibody.

\section{RESULTS}

The outbreak occurred during May-June, 2016 in buffaloes of a dairy farm located in the municipality of Bujaru $\left(1^{\circ} 37^{\prime} 38.7^{\prime \prime} \mathrm{S}\right.$; $48^{\circ} 13^{\prime} 21.3^{\prime \prime} \mathrm{W}$ ), microregion of Castanhal, Pará state, Brazil. This property held a herd of 750 Murrah buffaloes: 630 bulls and 120 calves. Calves were divided into batches according to age. Animals belonging to two batches sickened: Batches 1 and 2 composed of 12 and 35 animals, respectively, aged $<40$ days, kept in stalls with access to Brachiaria brizantha and Panicum maximum (cv. mombaça) pastures. Twice a day, the calves were placed with the suckling cows (after milking) and received commercial feed (approximately 400g per animal). Other animal species, such as chickens, horses and bulls, had access to the stalls and pastures where the calves were kept. In the farm where the outbreak occurred, the milk produced was used to make artisanal fresh cheese. 


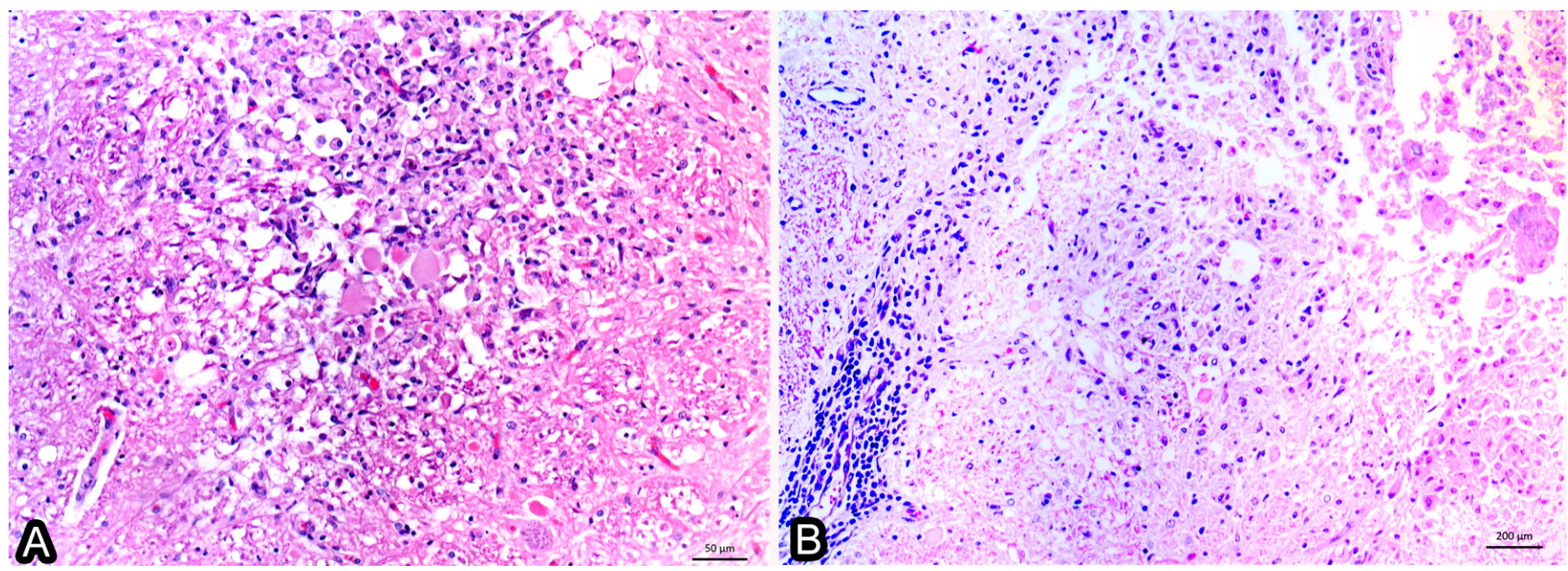

Fig.1. (A) Microabscess composed mainly of mononuclear cells, with few neutrophils. Axonal spheroids and neuropil vacuolation in brainstem of Buffalo 2. HE, obj.20x. (B) Malacia area with infiltration of Gitter cells, with some multinucleated cells, and adjacent mononuclear perivascular cuffs in brainstem of Buffalo 1. HE, obj.20x.

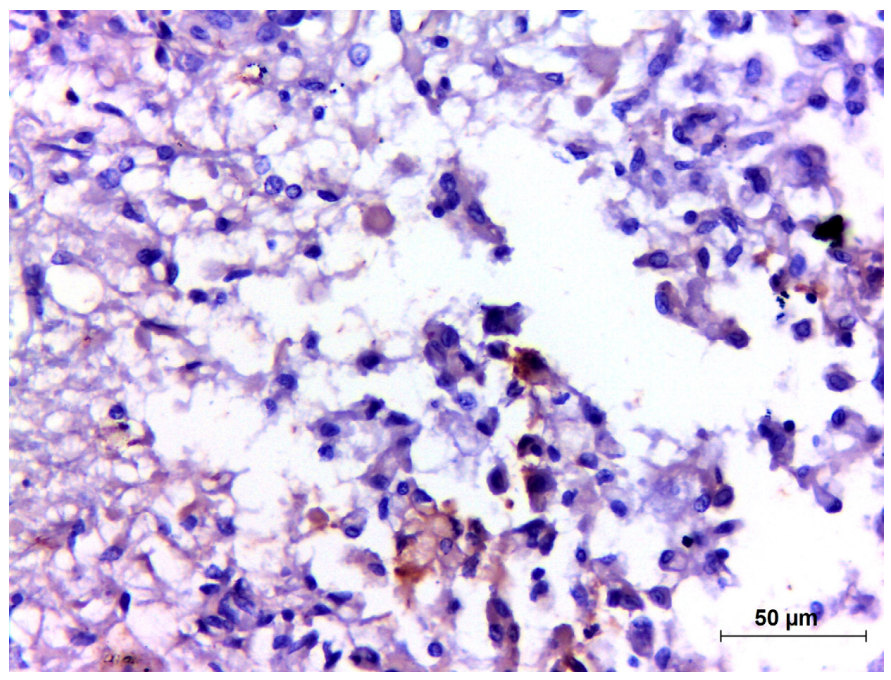

Fig.2. Anti-Listeria monocytogenes marking in the cytoplasm of macrophages in brainstem of Buffalo 1. IHC, obj.40x.

Two animals from Batch 1 (Calves 1 and 2) and one animal from Batch 2 (Calf 3) sickened and died. Morbidity was $6.38 \%$ $(3 / 47)$ and lethality was $100 \%$. According to the veterinarian, the three animals (Buffaloes 1, 2, and 3) presented clinical neurological condition consisting of mainly of ataxia, paralysis of the four limbs, decreased skin sensibility, lateral recumbency, and death, with 24-48h evolution. Sick buffaloes were treated with penicillin (20000UI/kg/bodyweight every $24 \mathrm{~h}$ ), but did not respond to the treatment. At necropsy, no significant macroscopic lesions were observed. Histopathology of the brainstem, tissue sections of the pons, showed multifocal, random microabscesses predominantly composed of mononuclear cells, with some polymorphonuclear cells (Fig.1A), and perivascular cuffs composed mostly of mononuclear cells and few neutrophils (Buffaloes 1, 2 and 3) (Fig.1B). In the areas adjacent to the microabscesses, neuronal necrosis, microgliosis, swollen astrocytes (Buffalos 1 and 2), and fibrinoid necrosis with thrombosis in blood vessels (Buffalo 2) were observed. Histopathology of tissue sections of the pons also showed Wallerian degeneration (Buffaloes 1 and 2) and malacia areas with neuropil vacuolation, with infiltration of Gitter cells, with some multinucleated cells (Fig.1B). In the cerebral cortex, areas of malacia were observed with gliosis (Buffalo 1) and mononuclear infiltrate in the meninges, which projected to the deep part of the white and gray matter (Buffaloes 1 and 2). The spinal cord showed Wallerian degeneration and unilateral demyelination in the lateral dorsal funiculi (Buffaloes 1 and 2) and unilateral (Buffalo 2) or bilateral (Buffalo 1) in the lateral ventral funiculi. There were also discrete perivascular cuffs (Buffaloes 1 and 2) and mixed inflammatory infiltrate with mononuclear and polymorphonuclear cells in the meninges (Buffalo 2). Discrete meningitis with mixed infiltrate was observed in the cerebellum of Buffalo 3. In this animal, changes in autolysis ranged from moderate to severe. No significant changes were found in the other organs.

The Gram's stain technique performed in tissue sections of the pons from Buffaloes 1 and 2 revealed Gram-positive cocci in the malacia area and adjacent neuropil. IHC was positive in the microabscesses of Buffalo 1, with moderate multifocal staining in the cytoplasm of macrophages and adjacent debris (Fig.2), whereas no staining was observed in Buffaloes 2 and 3.

\section{DISCUSSION}

In the present study, diagnosis of listeric meningoencephalitis was based on epidemiological data and on the pathological clinical condition of the animals, and was confirmed by immunostaining for Listeria monocytogenes. The histological changes observed in the buffaloes involved in the present outbreak are similar to those described in the literature in cattle and small ruminants (Oevermann et al. 2010, Headley et al. 2013).

The most significant lesions occurred in the brainstem, and were found unilaterally and characterized mainly by microabscesses, areas of malacia, and perivascular cuffs, similar to what has been observed in cattle (Sanches et al. 2000, 
Oevermann et al. 2010, Margineda et al. 2012), goats (Rissi et al. 2006, Headley et al. 2013), and sheep (Rissi et al. 2010, Headley et al. 2013).

Microabscesses are considered as typical of this disease, and are formed by neutrophil infiltrates, with varying numbers of macrophages. The cell types that compose the microabscesses enable assessment of encephalopathy progression, classifying it as acute, when the microabscess presents a larger number of neutrophils, whereas in the most advanced cases, macrophages prevail over neutrophils and there is presence of multinucleated cells (Oevermann et al. 2010). In the present report, despite the short evolution time of the disease, which varied from 24 to $48 \mathrm{~h}$, the microabscesses were formed by large numbers of macrophages and giant multinucleated cells and few neutrophils. Oevermann et al. (2010) observed that the microabscesses show a larger number of macrophages in cattle than in small ruminants, and that occurrence of giant multinucleated cells, as observed in the present study, is significantly higher in cattle compared with sheep and goats. Perivascular cuffs were composed predominantly of mononuclear cells with rare polymorphonuclear cells, and extended from the brainstem to the cerebral cortex and spinal cord, findings also observed in cattle (Galiza et al. 2010, Margineda et al. 2012) and small ruminants (Campero et al. 2002, Headley et al. 2013).

When the neurological symptoms and the histopathological lesions are suggestive of listeriosis, diagnosis can be confirmed by culture, detection of the microorganism by special staining (Gram's stain), IHC, or polymerase chain reaction (PCR) (Campero et al. 2002, Loeb 2004). In this study, Gram-positive bacteria compatible with Listeria spp. were observed in the lesions of Buffaloes 1 and 2 . However, only one of the animals tested positive by IHC. This finding differs from those reported in other studies conducted with cattle and small ruminants (Rissi et al. 2006, 2010, Oevermann et al. 2010, Margineda et al. 2012), which showed positive results by IHC in all of the animals analyzed. Nevertheless, differences in IHC staining have been observed in cases of listeriosis in goats, ranging from strong to absent, depending on the time of lesion evolution (Rissi et al. 2006). Pfister et al. (2002) demonstrated that, in listeriosis, the production capacity of nitric oxide is higher in cattle compared with that in small ruminants and that this substance may result in weak or absent immunostaining for the disease antigen, considering that it regulates intracellular bacterial growth. This fact could explain the absence of staining in Buffaloes 2 and 3. Another factor that may have interfered with the immunostaining in Buffalo 3 is the autolysis of the material available for analysis. In Buffaloes 2 and 3, the diagnoses were based on clinical signs, histopathological lesions suggestive of the disease, and similarity between the clinical and pathological condition of these animals and that observed in Buffalo 1, which was positive by IHC.

The encephalic form of listeriosis affects mainly ruminants regardless for gender and age, and the disease is most frequently observed in the first three years of life (Gray \& Killinger 1996). In the present study, the disease affected calves aged $<40$ days. The main clinical signs observed by the veterinarian were ataxia, limb paralysis, lateral recumbency, and death, similar to those described for cattle (Margineda et al. 2012) and small ruminants (Rissi et al. 2006, 2010). Morbidity (6.38\%) and lethality $(100 \%)$ were also similar to those described for these species. In Brazil, listeric meningoencephalitis has been reported mainly in ruminants under extensive farming with no history of feeding on silage, and occurring in the hottest months of the year (Rissi et al. 2010, Sanches et al. 2010) or in the transition period between the rainy and dry seasons (Guedes et al. 2007), epidemiological characteristics similar to those observed in the present outbreak, which occurred in the transition between the rainy and dry seasons in the region.

It was not possible to determine the source of infection in the present study, but chickens, horses, and bulls had contact with the calves, including access to the troughs where the feed was provided, and thus could serve as a source of infection. In outbreaks of listeriosis in goats and sheep in the state of Rio Grande do Sul, contaminated pasture or feed and direct contact with feces from other species such as chickens and pigs were considered as possible sources of infection (Rissi et al. 2006, 2010). According to George (2002), cases of meningoencephalitis not related to feed are commonly associated with environmental contamination. Clinically healthy bovines are carriers of L. monocytogenes and eliminate the bacterium along with their feces (Wesley 1999). Another source of infection that should be considered in this outbreak is the mother's milk, since for cattle elimination of L. monocytogenes through milk has been described after mastitis or abortions (Quinn et al. 2001).

Because the possibility of listeriosis was not considered during the clinical care of the animals, the oral cavities were not analyzed at necropsy. However, a possible gateway of the bacterium to the central nervous system could be the eruption of the teeth. In buffaloes, the first three pairs of primary incisor teeth erupt within the first three months of life, with the first pair erupting up to the $7^{\text {th }}$ day and the others with intervals ranging from 14 to 30 days of life (Seixas et al. 2007), a period that coincides with the age, sickening, and death of the animals of the present study.

This is the first report of encephalic listeriosis in buffaloes, as well as the first report of disease occurrence in ruminants in the Brazilian Amazonia. The diagnosis of listeric meningoencephalitis in dairy buffaloes highlights the importance of these animals and their products as possible sources of infection by $L$. monocytogenes for humans. Consumption of bovine raw milk, pasteurized milk, and cheese, usually soft, fresh or mature, has been associated with outbreaks of human listeriosis (Silva et al. 2011).

\section{CONCLUSIONS}

The encephalic form of listeriosis occurs in buffaloes in the state of Pará, Brazil, and this disease should be considered in the differential diagnosis of buffaloes with neurological syndrome.

Occurrence of listeric meningoencephalitis in a herd of dairy buffaloes warns about the importance of this zoonosis, especially when the milk is used to produce artisanal fresh cheese.

Acknowledgements.- The authors are grateful to Coordenação de Aperfeiçoamento de Pessoal de Nível Superior (CAPES) for the grant provided to the first author.

Conflict of interest statement. - The authors declare no conflicts of interest. 


\section{REFERENCES}

Campero C.M., Odeon A.C., Cipolla A.L., Moore D.P., Poso M.A. \& Odriozola E. 2002. Demonstration of Listeria monocytogenes by immunohistochemistry in formalin-fixed brain tissues from natural cases of ovine and bovine encephalitis. J. Vet. Med. B, Infect. Dis. Vet. Public Health 49(8):379-383. <http://dx.doi.org/10.1046/j.1439-0450.2002.00586.x><PMid:12449246>

Galiza G.J., Silva M.L., Dantas A.F., Simões S.V. \& Riet-Correa F. 2010. Doenças do sistema nervoso de bovinos no semiárido nordestino. Pesq. Vet. Bras. 30(3):267-276. <http://dx.doi.org/10.1590/S0100-736X2010000300014>

George L.W. 2002. Listeriosis, p.946-949. In: Smith B.P. (Ed.), Large Animal Internal Medicine. 3rd ed. Mosby, St Louis.

Gray M.L. \& Killinger A.H. 1996. Listeria monocytogenes and listeric infections. Bacteriol. Rev. 30(2):309-382. <PMid:4956900>

Guedes K.M.R., Riet-Correa F., Dantas A.F.M., Simões S.V.D., Miranda Neto E.G., Nobre V.M.T. \& Medeiros R.M.T. 2007. Doenças do sistema nervoso central em caprinos e ovinos no semiárido. Pesq. Vet. Bras. 27(1):29-38. <http://dx.doi.org/10.1590/S0100-736X2007000100006>

Headley S.A., Bodnar L., Fritzen J.T., Bronkhorst D.E., Alfieri A.F., Okano W. \& Alfieri A.A. 2013. Histopathological and molecular characterization of encephalitic listeriosis in small ruminants from northern Paraná, Brazil. Braz. J. Microbiol. 44(3):889-896. <http://dx.doi.org/10.1590/S151783822013000300036><PMid:24516457>

Jones T.C., Hunt R.D. \& King N.W. 2000. Patologia Veterinária. 6ª ed. Manole, Barueri. 1415p.

Konradt G., Bassuino D.M., Prates K.S., Bianchi M.V., Snel G.G.M., Sonne L., Driemeier D. \& Pavarini S.P. 2017. Suppurative infectious diseases of the central nervous system in domestic ruminants. Pesq. Vet. Bras. 37(8):820828. <http://dx.doi.org/10.1590/s0100-736x2017000800007>

Loeb E. 2004. Encephalitic listeriosis in ruminants: immunohistochemistry as a diagnostic tool. J. Vet. Med. 51(9/10):453-455. <http://dx.doi. org/10.1111/j.1439-0442.2004.00656.X> <PMid:15610491>

Low J.C. \& Renton C.P. 1985. Septicaemia, encephalitis and abortus in a housed flock of sheep caused by Listeria monocytogenes type $1 / 2$. Vet. Rec. 116(6):147-150.<http://dx.doi.org/10.1136/vr.116.6.147><PMid:3920813>

Margineda C.A., Cantón G., Lischinsky L., Moreira A. \& Campero C.M. 2012. Listeriosis en bovinos de la Provincia de Buenos Aires, Argentina. Revta Vet. 23(1):32-37.

Mendes T.C., Ferreira J.L.M., Azambuja V.B., Ladeira S.L., Tortelli F.P., Pereira G.M. \& Raffi M.B. 2005. Listeriose em ovinos. Arq. Bras. Med. Vet. Zootec. 57(Suppl.1):36.

Oevermann A., Di Palma S., Doherr M.G., Abril C., Zurbriggen A. \& Vandevelde M. 2010. Neuropathogenesis of Naturally Occurring Encephalitis Caused by Listeria monocytogenes in Ruminants. Brain Pathol. 20(2):378-390. <http://dx.doi.org/10.1111/j.1750-3639.2009.00292.x><PMid:19476464>
Pfister H., Remer K.A., Brcic M., Fatzer R., Christen S., Leib S. \& Jungi T.W. 2002 Inducible nitric oxide synthase and nitrotyrosine in listeric encephalitis: a cross-species study in ruminants. Vet. Pathol. 39(2):190-199. <http:// dx.doi.org/10.1354/vp.39-2-190><PMid:12009057>

Quinn P.J., Markey B.K., Carter M.E., Donnelly W.J. \& Leonard E.C. 2001. Veterinary Microbiology and Microbial Disease. Blackwell Publishing, Oxford, p.72-75.

Ribeiro L.A.O., Rodrigues N.C., Fallavena L.C.B., Oliveira S.J. \& Brito M.A. 2006. Listeriose em rebanho de ovinos leiteiros na região serrana do Rio Grande do Sul: relato de caso. Arq. Bras. Med. Vet. Zootec. 58(3):316-319. <http:// dx.doi.org/10.1590/S0102-09352006000300005>

Rissi D.R., Fighera R.A., Irigoyen L.F., Kommers G.D. \& Barros C.S.L. 2010 Doenças neurológicas de ovinos na região central do Rio Grande do Sul. Pesq. Vet. Bras. 30(3):222-228. <http://dx.doi.org/10.1590/S0100736X2010000300006>

Rissi D.R., Rech R.R., Barros R.R., Kommers G.D., Langohr I.M., Pierezan F. \& Barros C.S. 2006. Forma nervosa de listeriose em caprinos. Pesq. Vet. Bras. 26(1):14-20. <http://dx.doi.org/10.1590/S0100-736X2006000100004>

Sanches A.W.D., Langohr I.M., Stigger A.L. \& Barros C.S.L. 2000. Doenças do sistema nervoso central em bovinos no sul do Brasil. Pesq. Vet. Bras. 20(3):113-118. <http://dx.doi.org/10.1590/S0100-736X2000000300005>

Schneider D.J. 1994. Listeriosis, p.1374-1377. In: Coetzer J.A.W., Thompson G.R. \& Tustin R.C. (Eds), Infectious Diseases of Livestock. Vol.2. Oxford University, New York.

Seixas V.N., Cardoso E., Araújo C., Pereira W.L. \& Viana R.B. 2007. Determinação da cronologia dentária de machos bubalinos (Bubalus bubalis) criados no estado do Pará. Ciênc. Anim. Bras. 8(3):529-535.

Silva A.S., Aragon C.C., Santana E.H.W., Destro M.T., Costa M.R. \& Alegro L.C.A. 2011. Listeria monocytogenes em leite e produtos lácteos no Brasil: uma revisão. UNOPAR Cient., Semina, Ciênc. Biol. Saúde, Londrina 13(1):59-67.

Summers B.A., Cummings J.F. \& de Lahunta A. 1995. Listeriosis, p.133-135. In: Ibid. (Eds), Veterinary Neuropathology. Mosby, Baltimore.

Vandegraaff R., Borland N.A. \& Browning J.W. 1981. An outbreak of listerial meningoencephalitis in sheep. Aust. Vet. J. 57(2):94-96. <http://dx.doi. org/10.1111/j.1751-0813.1981.tb00457.x><PMid:7259653>

Wang Y., Lu L., Lan R., Salazar J.K., Liu J., Xu J. \& Ye C.H. 2017. Isolation and characterization of Listeria species from rodents in natural environments in China. Emerg. Microbes Infect. 6(6):e44. <PMid:28588285>

Wesley I.V. 1999. Listeriosis in animals, p.39-73. In: Ryser E.T. \& Marth E.H (Ed.), Listeria, Listeriosis and Food Safety. 2nd ed. Marcel Dekker, New York.

Wilesmith J.W. \& Gitter M. 1986. Epidemiology of ovine listeriosis in Great Britain. Vet. Rec. 119(19):467-470. <http://dx.doi.org/10.1136/ vr.119.19.467><PMid:3788010> 